\title{
IMPLEMENTATION OF ICONIC CARD BASED MALAY CULTURAL VAlues in Developing Character Education of Senior High SCHOOL STUDENTS
}

\author{
Juliana \\ Faculty of Social Science and Education, Universitas Potensi Utama
}

juliana@potensi-utama.ac.id

\begin{abstract}
The lack of the students ' interest and attention toward the local wisdom values of the local culture is this research background. The phenomena are due to the absence of interactive media to strengthen character education based on local wisdom in school. The purpose of this research is to create an interactive media based on local wisdom values with the implementation of the iconic card to strengthen the local wisdom values of Malay culture which is useful to build students' character education. The research used a qualitative descriptive method with social anthropological lnguistics approach. The subject of this research was students of Nurul Hasanah Senior High School, Medan. The data were collected through field observation, interview, and documentation. The results showed that the iconic cardis used as a media to teach Malay wisdom values with the use of the Pak Belalang icon and Malay pantun. Pantun in this research has local wisdom values of Malay culture such as moral, ethical and norm values.
\end{abstract}

Keywords: malay cultural values, iconic card, pantun

\section{INTRODUCTION}

At present, Indonesian community is being stirred up by various problems related to violence committed by some students in various regions. One example of the recent violence is a case of violence between students around Taman Ahmad Yani, Medan. This phenomenon is due to the lack of character education in schools, since school is a stakeholder to teach and strengthen the values of character education of students in creating the quality of human resources (Rosala, 2017). For this reason, efforts are needed to strengthen character education developing cultural human resources. One effort to build character education is through enhancing the values of local wisdom (Ghufronudin et al., 2017).

Strengthening character education through local wisdom values needs to be done by stakeholders in schools, so that students increasingly recognize the nation's culture while loving cultural diversity (Rasid, 2014). The material from local knowledge can be used as learning materials for cultural contextual character education as a solution to face the challenges of globalization (Komara, 2018), . Therefore, education in Indonesia creates the advantage of character education in the culture of local knowledge in facing globalization. Through character education based on local wisdom not only creates intellectually intelligent human resources but is also able to produce individuals who possess cultural intelligence who hold fast to national identity (Juliana, Fatimah, 2018).

In developing local wisdom material, it is expected that creative educators integrate local wisdom with the content in the School by taking up the theme of local culture, namely Malay culture so that students can recognize and love the culture of the local community (Fajarini, 2014) Malay culture is known as through literary works in the form of pantuns. The pantun is a Malay poetic form and originated as a traditional oral form of expression (Wikipedia). Pantun can be used as a media to strengthen the local wisdom values of Malay culture, which contain messages, mandates, and advices of Malay ethnic. The intelligence of a language educator in transferring knowledge to students through figurative language is very appropriate to be used through pantun to provide awareness for young people to recognize local culture in the city of Medan, especially Malay culture so that the knowledge they receive is not only useful but also provides messages and moral methods containing the values of local wisdom that are full of advice in it.

Besides, pantuns are also able to form the character of students who are intellectually cognitive and synergize with skills and ethics (Mat, 2006). He formulates that the literary component that is taught formally can help to give birth to a group of knowledgeable, skilled and noble people. The skill of arranging words in pantuns can be used as a measure of one's intelligence level because the language in pantuns contains figurative meanings (Juliana, 2019). A wise person uses the figurative language contained in poetry; it can be said that he is a knowledgeable person (Kusmayadi, 2006). One of the media to teach the wisdom values of Malay culture through pantun is to use iconic media. 
Iconic cards can be used as an interactive media based on local wisdom by applying the iconic character of Pak Belalang who is well-known in Malay folklore and also pantun that are full of advice and advice from the lives of Malay people so that these two cultural icons can be used as a medium to introduce Malay culture (Juliana, Fatimah, 2018). Local wisdom can be found in folklore inherent in particular community groups and can also be expressed in the form of wise words in the form of proverbs, pantuns, folklore (oral stories) and so on (Anggraeni, N., \& Haryanto, 2013). One of the culture-based learning models can be done through folklore and proverbs or pantuns that contain life's advice and mandate (Wuryandani, 2010). Besides, it can be said that the iconic media card is one of the effective media in helping students understand the local wisdom values of Malay culture because it is presented with pantuns that are full of messages and advice from ethnic Malays as well as the character of Pak Belalang as an icon of conveying information about pantuns (Indra, 2013) (Anharoeni Vina, 2018). In this case, the students are trained, guided and fostered to familiarize themselves in understanding the local wisdom values of Malay culture in pantuns so as to shape the students' good character (Yekti Mahanani, 2015). For students, the implementation of wisdom value of Malay culture through pantuns can provide insight and knowledge in recognizing and promoting local Malay culture as a form of preservation of local wisdom. This is done by introducing the types of pantuns, the values of the local wisdom of the pantun and folklore Pak Belalang. The pantuns used in this study were adjusted to the character-building of the students. The teaching system and method use the media of pictorial icons of Pak Belalang folklore figures that are presented interactively so as to stimulate students cognitive and affective intelligence (Juliana, 2019)

From the background above, this research aims to implement the values of Malay local wisdom in building the character education of students of Nurul Hasanah Senior High School. Through the use of iconic cards, namely interactive learning media that enable students to understand the basic concepts of pantun, and make messages delivered to students becomes compelling, so that the interest and participation of students to love and apply the values of local wisdom increases.

\section{MATERIALS AND METHODS}

\subsection{RESEARCH DESIGN}

This research employs a qualitative descriptive method with a social anthropology approach. In this research, researcher studied the wisdom values of Malay culture and its development in education (Hammersley, 2018). This research is located in Nuruh Hasanah Senior High School at Jalan Amal Bakti No. 69 Tembung, Kecamatan Percut Sei Tuan, and Postal code 20371 Medan.

The subjects of this research were 25 Eleventh grade Students of Nurul Hasanah Senior High School Medan in 2018/2019 academic year. The sample is chosen using purposive sampling, it means that only select students that has similar knowledge and background about Malay pantun before. The research was conducted when teaching Bahasa Indonesia lesson. The data were collected through observation, interview, and documentation.

\subsection{RESEARCH PROCEDURES}

The stages and procedures of the implementation of this research are described as follows:

\subsubsection{PREPARATION OF MATERIAL AND IMPLEMENTATION OF RESEARCH}

Preparation of material and application of research carried out by preparing material that supports the implementation of research including making materials and media for teaching the values of local wisdom of Malay culture using iconic cards by applying local wisdom values of Malay culture in the form of Pak Belalang and Malay pantun.

\subsubsection{CONDUCTING THE RESEARCH}

Conducting the research is one of the solutions for teaching the values of Malay cultural wisdom to Nurul Hasanah High School students by using the pantun-based Malay iconic card and Pak Belalang icon. This research was conducted by optimizing the creative potency of Nurul Hasanah high school students in producing pantun, teaching the local wisdom values of Malay culture using Pak Belalang icon and Malay pantun in the form of moral, ethics and norms values, and developing teaching innovative media using iconic cards based on the character icon of Pak Belalang and the pantun. Third Stage: Data are analyzed using Miles and Huberman's theory (1998) interactive data analysis procedures and models. 


\subsubsection{INTERACTIVE DATA ANALYSIS}

Interactive data analysis in describing the process of conducting this research is as follows (Huberman, 1998). Firstly, data reduction was conducted by selecting pantun that used in the research to adjust to the research objectives. The selection of pantun was adjusted from the cultural values to build students' character education. Secondly, data presentation by presenting ways, methods, media and teaching activities of the local wisdom values of Malay culture to the students of Nurul Hasanah High school through the use of pantun and icon of Pak Belalang. Lastly, Thirdly, Conclusion drawing by making conclusions from the results of the analysis of field data regarding the way, the process of teaching the local wisdom values of Malay culture through the iconic card to students of Nurul Hasanah Senior High School. In other words, the data is described, discussed, and concluded. Fourth Stage: Evaluation of the implementation of research by conducting supervision and providing advice on the implementation of activities to students of Nurul Hasanah Senior High School Medan. This stage was done to give a solution to the problems and obstacles faced by students of Nurul Hasanah Senior High School after the research was completed.

\section{RESULTS AND DISCUSSION}

\subsection{Local Wisdom VALUES OF MALAY CULTURE}

The process of teaching the values of Local Wisdom of Malay Culture is carried out by providing an introduction and direction on the basic concepts of local wisdom values of Malay culture through the poems and folklore of the iconic character of Pak Belalang to students of Nurul Hasanah senior high school, Medan. The process of teaching local Malay cultural wisdom values consists of several stages as follows:

\subsubsection{LOCAL WISDOM VALUES IN MALAY PANTUN}

In this case, the teaching process of the local wisdom values of the Malay pantun is carried out by providing knowledge to students of Nurul Hasanah Senior High School about the types, values and functions of the Malay pantun. The local wisdom values of the Malay pantun taught include religious values, politeness, tolerance, compassion, honesty, customs, character and loyal friends. (Abidin, M. I. Z., \& Razak, 2003). Here are a few pictures showing examples of Malay rhymes that contain local wisdom values of Malay culture on iconic cards:

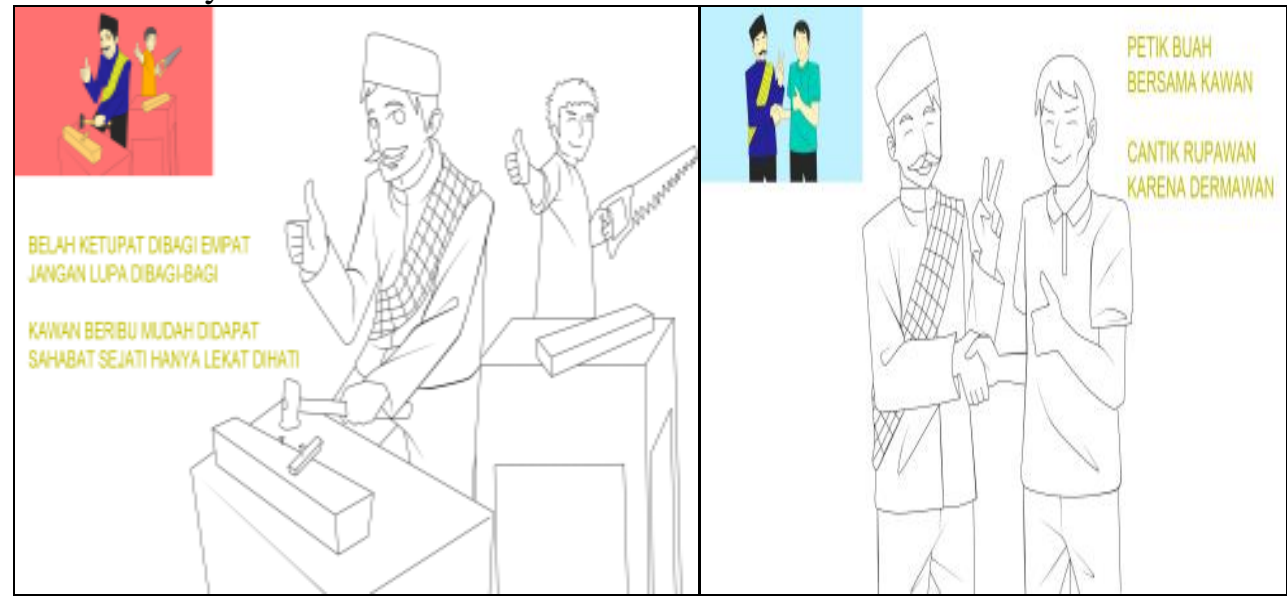

Figure 1: Iconic Card Based on Friendship and Generous Values

In this figure 1, the pantun used is the rhombus is divided in four. Don't forget to split it up, hunting buddies are easy to get, true friends are only closely attached to the heart. From this pantun reflects the local wisdom value of Malay culture, namely the value of friendship. In the next figure, there is a pantun which shows the local wisdom value in the form of the tolerance value contained in the pantun pick fruit with friends, Beautiful and, handsome persons because generous. 


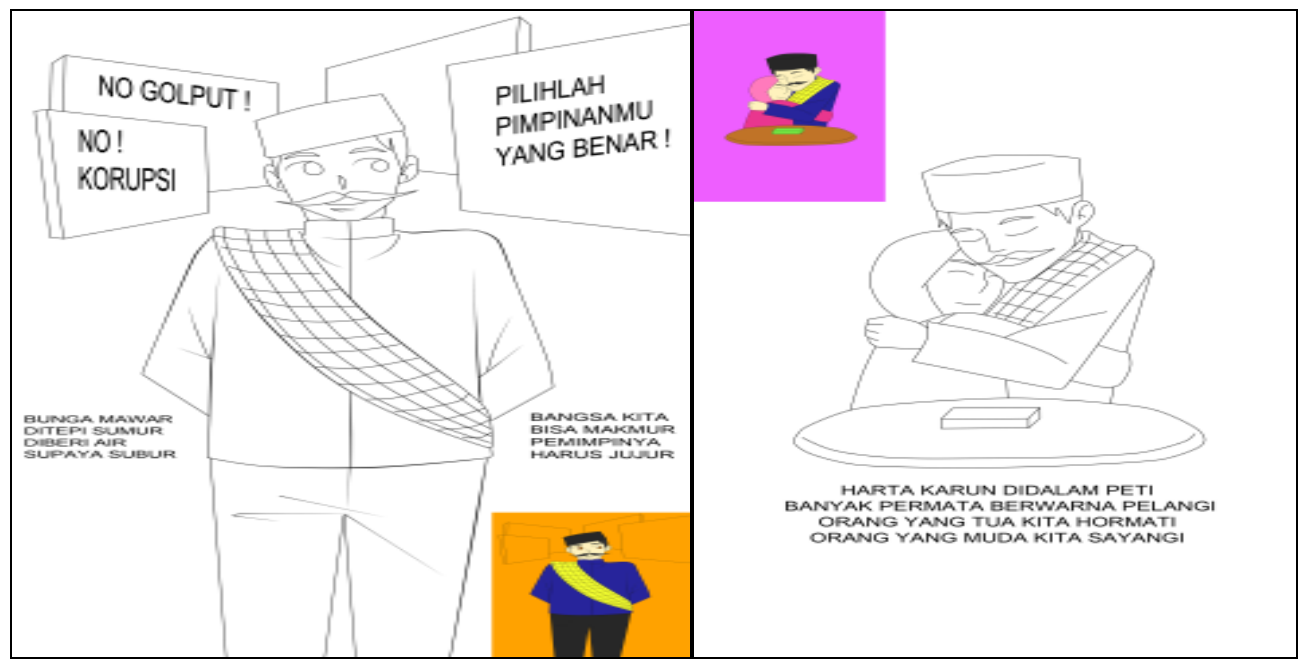

Figure 2: Iconic Card Based on Honesty and Good Manner Values

In the figure 2 the pantun used is the roses are on the edge of the well, given water to be fertile, our nation can prosper, its leaders must be honest. From this pantun reflects the local wisdom value of Malay culture in the form of honesty. In the next picture, there is the pantun which shows the local wisdom value in the form of respect for the values contained in the pantun treasures in a chest, many rainbow-colored gems, old people we respect, young people we care about.

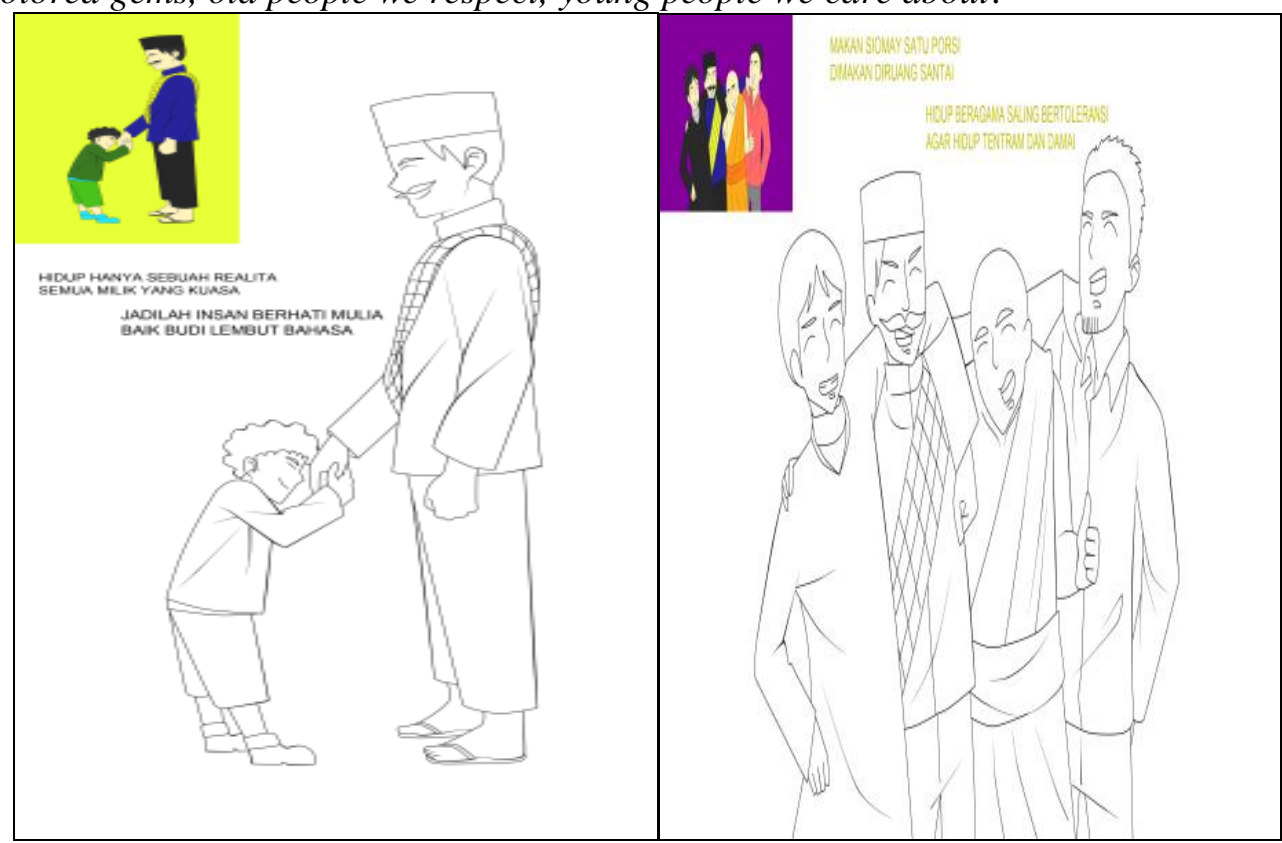

Figure 3: Iconic Card based on Politeness and Tolerance Values

In the figure 3, there is the pantun life is only a reality, dusk belongs to the powerful, be noble and kindhearted, gentle language. From this pantun contains the wisdom value in the form of politeness. In the next figure there is the pantun eat one portion of dumplings, eaten in a relaxed room, religious life and tolerate each other, so that you can live peacefully. This pantun contains wisdom value in the form of tolerance value.

\subsubsection{LOCAL WISDOM VALUES OF PAK BELALANG FOLKLORE}

Effendi (2019) states that if you want to see the customs, culture and the Malay community, then look at from literature or folklore. (Abidin, M. I. Z., \& Razak, 2003). This is in accordance with the function of literature and folklore can be used as a tool to teach and educate the community character including the presence of good teaching about ethical, moral values such as honesty, politeness, loyalty, kinship and etc. (Abidin, M. I. Z., \& Razak, 2003). Besides, there are also advice and messages not to be carried out such as advice and prohibitions not to do things that are not good, namely jealousy, arrogant, arrogant, spiteful, greedy, cunning, and so on. 
From the folklore of Pak Belalang by Dedi Rinjaya (2016), (Effendi, 2019), there are two main characters, namely Pak Belalang and King. The excellent character conveyed to the students of Nurul Hasanah Senior High School in this research is in the form of the role Pak Belalang as the main character who has an original role. Message and mandate to students of Nurul Hasanah Senior High School is in everyday life to solve a problem requires expertise and ingenuity in order to obtain a solution to a problem. (Abidin, M. I. Z., \& Razak, 2003) In addition, the nature and character of the King taught to students of Nurul Hasanah senior high school is as a decisive leader. To be a leader, you should have a firm and wise nature. This is necessary to decide on a problem precisely and not biased. These two values of goodness are then taught and conveyed to the private high school student Nurul Hasanah to be applied in life. In addition, the message and the mandate from Pak Belalang folklore is also conveyed to students of Nurul Hasanah Senior High School that to get success requires hard work and effort. Do not expect luck to reach happiness, and also do not believe in the existence of predictions and astrologers because most astrologers and predictions are only in the form of deception.

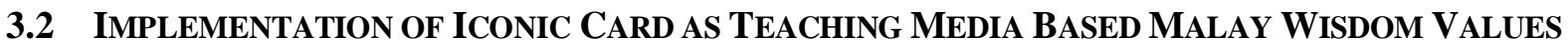

Malay pantun reflects the values of local wisdom and life of the Malay community, including the values of motivation, discipline, security, order, cleanliness and health. (Effendi, 2019)The following are some iconic media-based media on local wisdom of Malay culture applying the iconic character of Pak belalang and pantun Malay taught to students of Nurul Hasanah Senior High School, Medan.

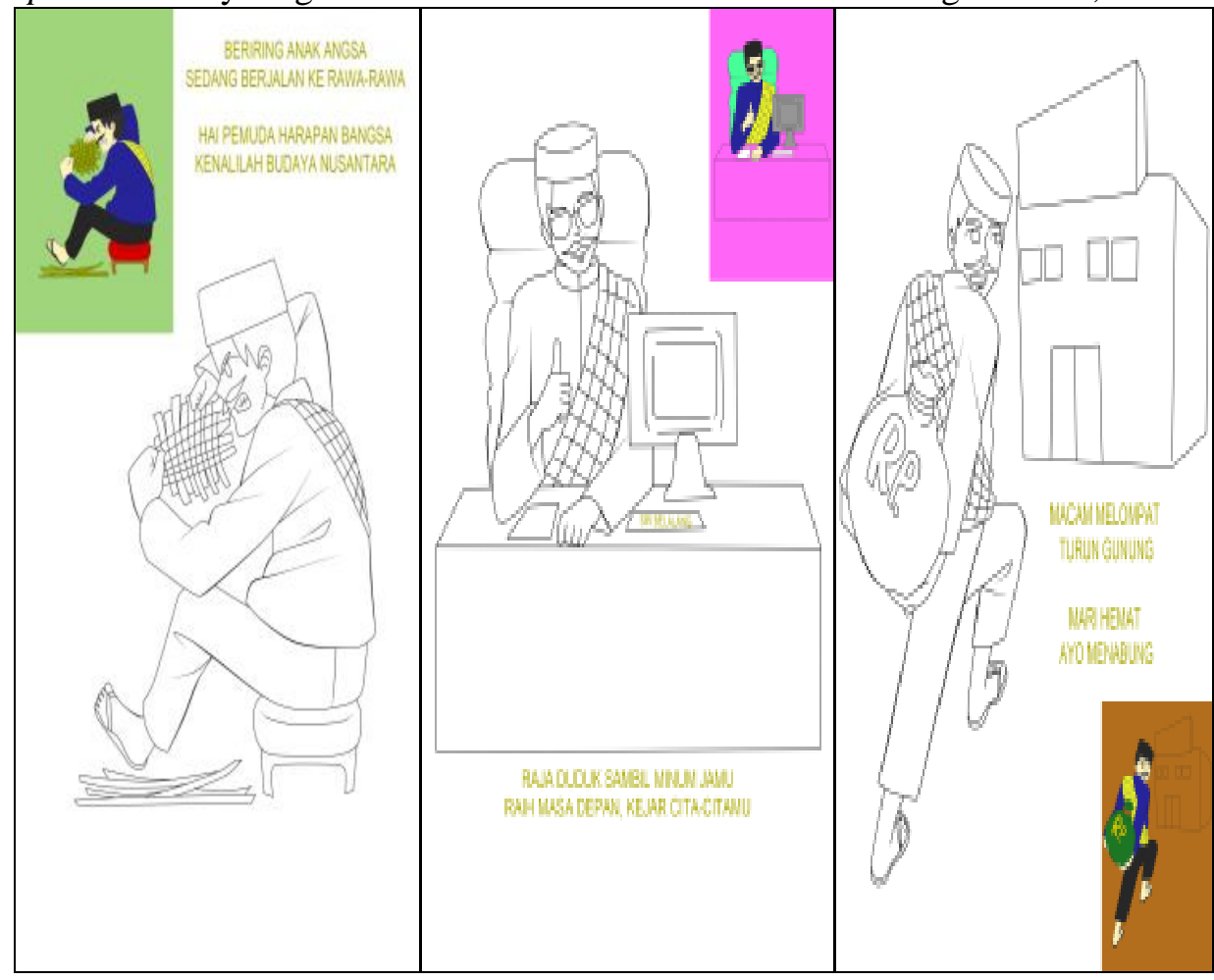

Figure 4: Iconic Card Based on Motivation Values 


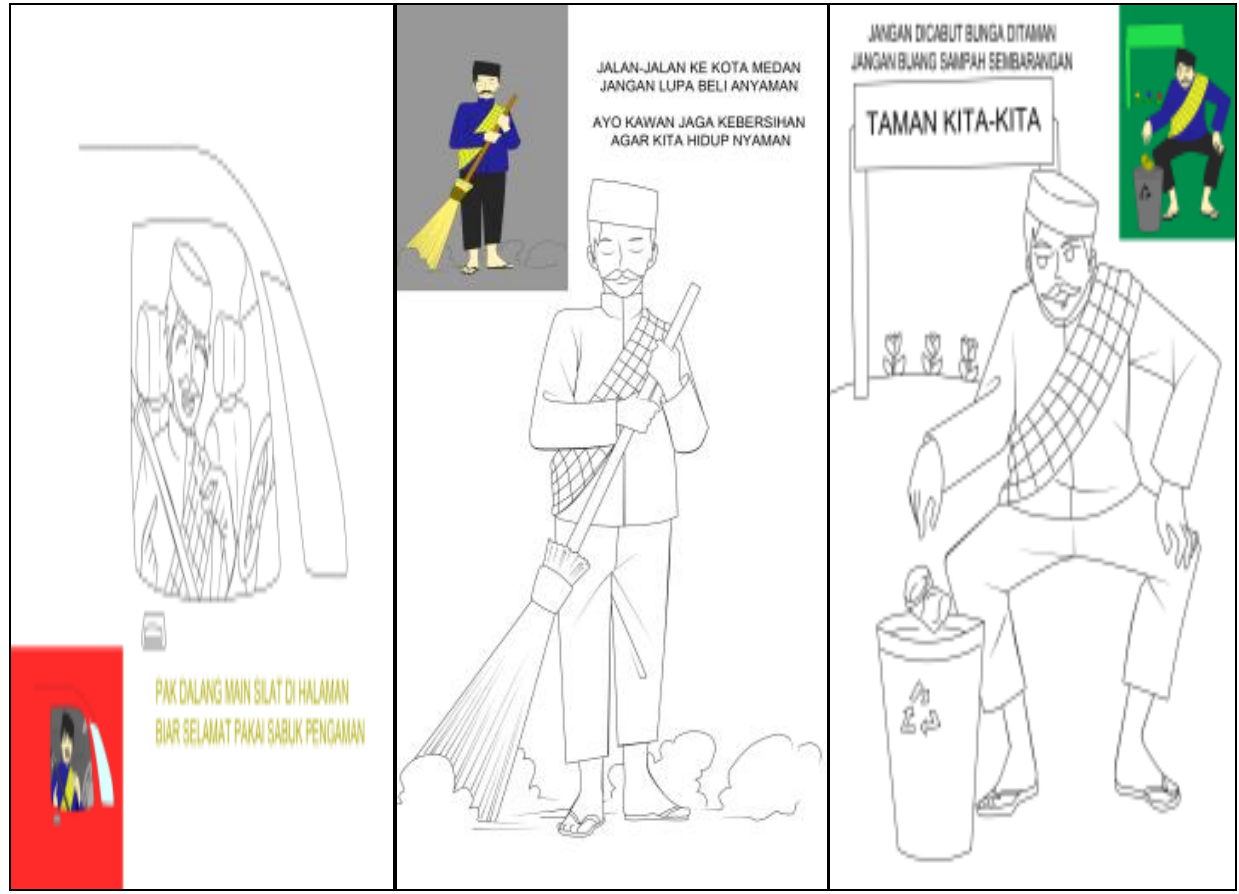

Figure 5: Iconic Card Based on Discipline, Cleanliness, and Orderliness Values

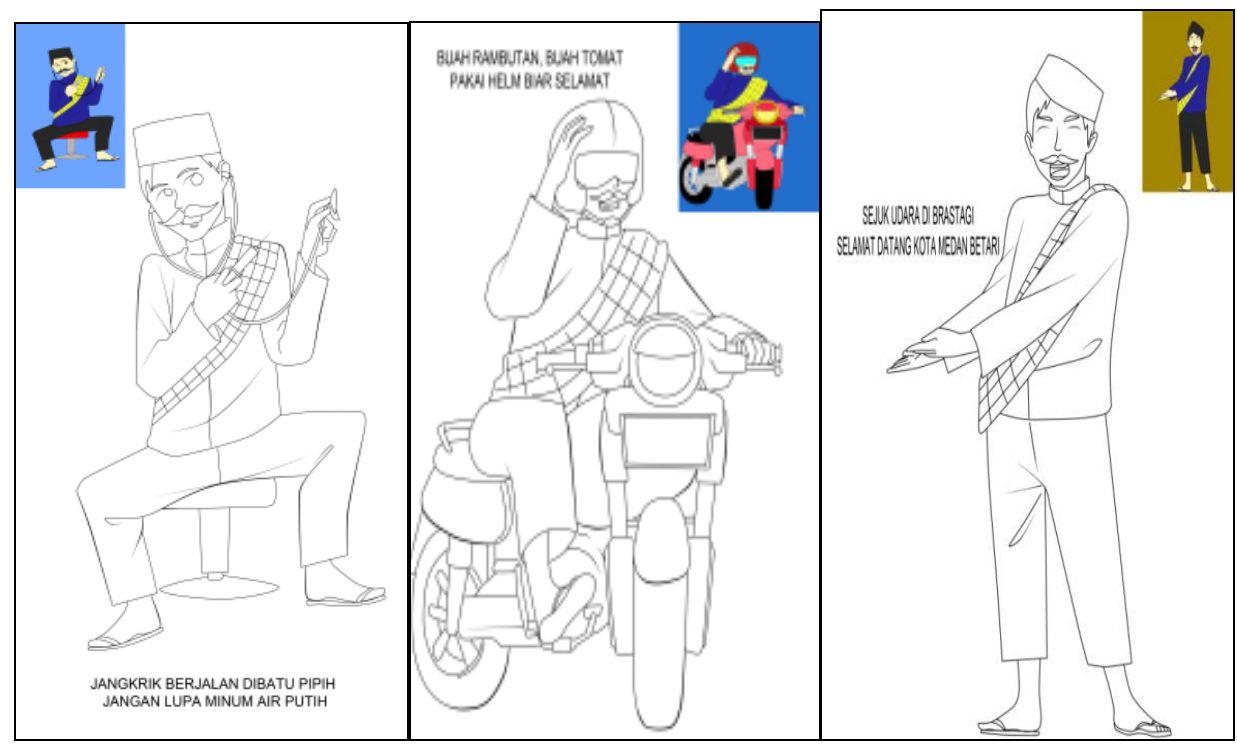

Figure 6: Iconic Card Based Healthy, Safety, and Friendly Values

\subsection{RESPONSES AND QUESTIONNAIRES}

The responses of the students of Nurul Hasanah Senior high school to the teaching of the local wisdom values of the Malay culture through iconic cards applying the Malay pantun and Pak Belalang was carried out to obtain information from the respondent in terms of reportson his personality, or things he knew (Arikunto, 2019). This instrument was arranged based on indicators that can express knowledge, skills, and experience regarding teaching pantun using iconic cards.

The questionnaire was used to find some information about: (1) the interest of students of Nurul Hasanah Senior High School in teaching local wisdom values of Malay culture through the iconic card applying pantun and iconic character of Pak Belalang, (2) the active role of students in teaching values of local wisdom of Malay culture through iconic card media applying the pantun and icon of Pak Belalang, (3) the difficulties and ease faced by students of Nurul Hasanah Senior high school when participating in the teaching of local wisdom values of Malay culture through iconic card based on pantun and Pak Belalang (4) students' feeling after following the teaching of local wisdom values of Malay culture through the iconic card based on pantun and Pak Belalang icon and (5) students' 
knowledge after attending the Malay cultural local wisdom values assisted by iconic card media applying pantun and Pak Belalang.

The instrument for evaluating the effectiveness of research in the teaching of Malay local wisdom values through the iconic card was carried out using a questionnaire. There were 25 statements and distributed to students of Nurul Hasanah Senior High School, Medan. The calculation results of the given questionnaire instruments can be seen in the figure below:

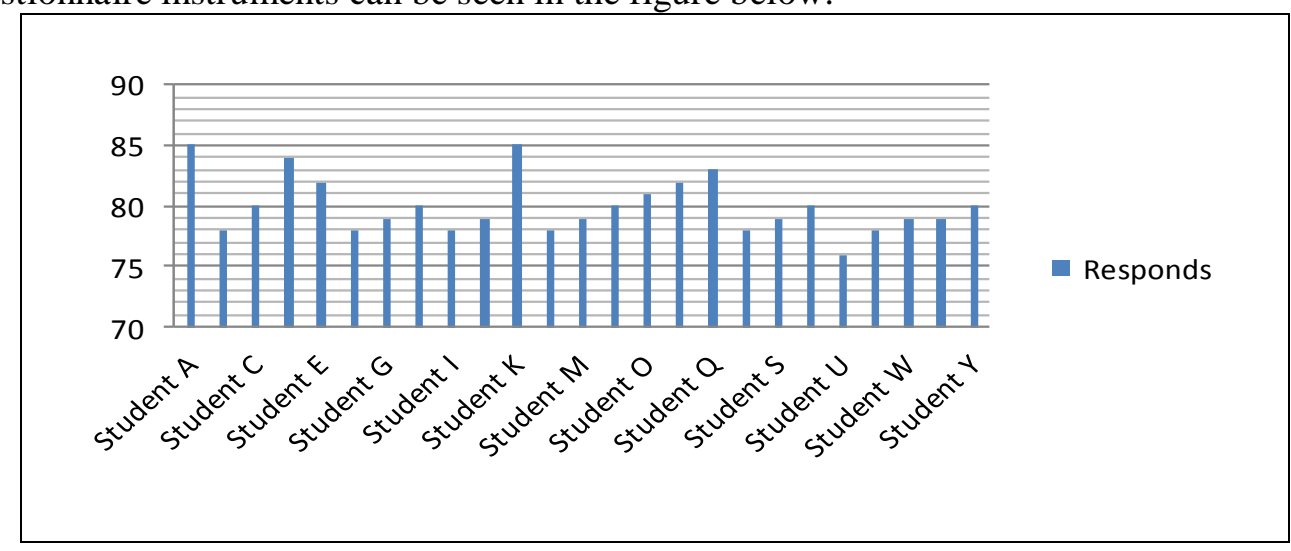

Figure 7: Responds of Teaching Malay Local Wisdom Values

The results of the questionnaire calculation of the implementation of research activities teaching the values of local cultural wisdom through the iconic card obtained an average percentage of questionnaires at a rate of 80.5 respondents liked this research activity. This is in accordance with the questionnaire calculation category which can be seen in Table 1 below (Arikunto, 2019).

The questionnaire was used to find some information about: (1) the interest of Nurul Hasanah Senior High School students in teaching local values of Malay culture through the iconic card applying pantun and iconic character of Pak Belalang, (2) the active role of students to participate in teaching values of local wisdom of Malay culture through iconic card media applying the pantun and icon of the Pak Belalang, (3) the difficulties and ease faced by high school students when attending the teaching of local wisdom values of Malay culture through the pantun-based iconic card and Pak Belalang icon (4) feelings students after following the teaching of Malay cultural local wisdom values through the pantunbased iconic card and Pak Belalang icon and (5) student knowledge after attending the Malay cultural local wisdom values assisted by iconic card media applying pantun and Pak Belalang.

The instrument for evaluating the effectiveness of researching the teaching of Malay local wisdom values through the iconic card was carried out using a questionnaire. Consisting of 25 statements and distributed to students of Nurul Hasanah Senior High School, Medan city. The calculation results of the given questionnaire can be seen in the figure below:

\begin{tabular}{|l|l|l|}
\hline No & Percentage Result & Category \\
\hline 1 & $80 \%-100 \%$ & Excellent \\
\hline 2 & $65 \%-79,99 \%$ & Good \\
\hline 3 & $55 \%-64,99 \%$ & Fair \\
\hline 4 & $40 \%-54,99 \%$ & Poor \\
\hline 5 & $0 \%-39,99 \%$ & Very Poor \\
\hline
\end{tabular}

Table 1: Evaluation Criteria (Jacobs et al 1981\& B North 2003)

Based on the assessment guidelines above, it can be seen that the response of students toward teaching the local wisdom values of Malay culture using the iconic card applying pantun and iconic character of Pak Belalang is as very good with a percentage of $80,5 \%$ categorized as very good. 


\section{CONCLUSION}

The results showed that the implementation of the local wisdom values through interactive media of iconic cards using Pak Belalang and pantun were able to improve the character education of students of Nurul Hasanah High School, Medan. In terms of knowledge aspect, students were able to understand basic material regarding types, functions and the local wisdom values of Malay culture include moral values including religious, politeness, tolerance, compassion, honesty, customs, character and loyal friends' values, and ethical values include honesty, politeness, loyalty, loyalty, family values. In terms of attitude and ethics aspects, students have the character of discipline and motivation in learning, courtesy to teachers, mutual respect for each other, have an awareness of obeying school rules, and maintain and preserve the culture of the community.

\section{REFERENCES}

Abidin, M. I. Z., \& Razak, A. A. (2003). Malay digital folklore: using multimedia to educate children through storytelling. Information Technology in Childhood Education Annual, 2003(1), 29-44.

Anggraeni, N., \& Haryanto, R. (2013). Kajian Harga Lahan sebagai Implikasi Perkembangan Aktivitas Komersial di Koridor Jalan Gajahmada, Kota Semarang. Teknik PWK (Perencanaan Wilayah Kota), 2(3), 368-377.

Anharoeni Vina. (2018). Pengembangan Kearifan Budaya Lokal Dalam Pembelajaran Sejarah Kebudayaan Islam DI SMP N 1 BANTUL. Universitas Islam Negeri Sunan Kalijaga.

Effendi, T. (2004). Tunjuk Ajar Melayu: Butir-Butir Budaya Melayu Riau. Yogyakarta: Balai Kajian Day Pengembangan Budaya

Effendi, R. (2019). Seeing Nature and the Philosophy of Banjar Through Banjar Traditional Pantun. Indonesian Journal of Cultural and Community Development, 2019(3), 1-9.

Fajarini, U. (2014). Peranan kearifan lokal dalam pendidikan karakter. SOSIO-DIDAKTIKA: Social Science Education Journal, 1(2), 123-130.

Ghufronudin, Zuber, A., \& Demartoto, A. (2017). Representasi-Pendidikan-Karakter Berbasis Kearifan Lokal melalui pembelajaran membatik. Jurnal Aanalsisi Sosiologi, 6(2), 30-37.

Hammersley, M. (2018). Routledge Revivals: What's wrong with Ethnography? (Routledge). Routledge.

Huberman, M. (1998). Qualitative data analysis: a methods sourcebook. In University Press of America. https://libgen.is/book/index.php?md5=8516FEB54168AFDB473061E7E4444EE1

Sage.

Indra, D. A. . (2013). Upaya Meningkatkan Pembelajaran Menulis Pantun Melalui Teknik Copy The Master. Bahtera Bahasa: Antologi Pendidikan Bahasa Dan Sastra Indonesia, 1(1), 1-13.

Jacobs, H. L. (1981). Testing ESL Composition: A Practical Approach. English Composition Program. Newbury House Publishers, Inc., Rowley, MA 01969.

Juliana, Fatimah, A. (2018). Pembinaan Penulisan Grafiti Sebagai Wadah Creative Entrepreneur Berbasis Kearifan Lokal Budaya Melayu Deli. Jurnal Ilmiah Lingua Idea, 9(2), 129-143. http://jos.unsoed.ac.id/index.php/jli/article/download/1135/903

Juliana Juliana, Fatimah Fatimah, A. A. (2018). Empowering and Fostering Creative Industries Entrepreneurs Based on Local Wisdom of Malay Deli. KARSA: Journal of Social and Islamic Culture, 26(2), 215-250. http://ejournal.stainpamekasan.ac.id/index.php/karsa/article/view/1829

Juliana Juliana, H. Z. (2019a). Revitalisasi Filosofi Ornamen Bermotif Melayu pada Desain Corak Anyaman Gedebong Pisang: Kajian Kearifan Lokal Budaya Melayu. Jurnal Ilmiah Lingua Idea, 10(1), 12-28. http://jos.unsoed.ac.id/index.php/jli/article/download/1541/1049

Juliana Juliana, H. Z. (2019b). The Philosophical Revitalization of Malay Motif Ornament in the Design of Woven Gedebong (Catri N Art, Rimbang Sekampung Village). The Second Annual International Conference on Language and Literature Volume 2019, 326-343. https://doi.org/DOI 10.18502/kss.v3i19.4868

Komara, E. (2018). Penguatan pendidikan karakter dan pembelajaran abad 21. Sipatahoenan, 4(1), 110.

Kusmayadi, I. (2006). Think Smart Bahasa Indonesia (P. G. M. Pratama. (ed.); PT Grafind). PT Grafindo Media

Pratama. https://books.google.co.id/books?hl=en\&lr=\&id=sp2aYkr3_4cC\&oi=fnd\&pg=PR3\&dq=ismail+ kusmayadi\&ots=0Glpjifxf9\&sig=Lxd pgWdKb5yhgop0 JGM2zupYk\&redir esc=y\#v=onepag $\underline{\mathrm{e} \& \mathrm{q} \& \mathrm{f}=\text { false }}$ 
Mat, N. (2006). Keperluan Teks Sastera dalam Pengajaran Bahasa Melayu. (44-47. Dewan Bahasa (ed.)).

North, B. (2003). Scales for rating language performance: Descriptive models, formulation styles, and presentation formats. Research Monograph Series. Princeton, NJ: Edu cational Testing Service.

Rasid, Y. (2014). Nilai-Nilai Kearifan Lokal ( Local Genius) Sebagai Penguat Karakter Bangsa. In Dr. Arifin Tahir (Ed.), Deepublish Publisher (Yogyakarta). Deepublish, Yogyakarta.

Rosala, D. (2017). Pembelajaran Seni Budaya Berbasis Kearifan Lokal Dalam Upaya Membangun Pendidikan Karakter Siswa Di Sekolah Dasar. Ritme, 2(1), 16-25.

Wuryandani, W. (2010). Integrasi nilai-nilai kearifan lokal dalam pembelajaran untuk menanamkan nasionalisme di sekolah dasar. Proceding Seminar Nasional Lembaga Penelitian UNY, 1-10. https://doi.org/10.1017/CBO9781107415324.004

Yekti Mahanani, A. (2015). Peningkatan Keterampilan Memproduksi Teks Pantun Secara Tulis Dengan Metode Tulis Berantai Melalui Media Kartu Pintar Pada Peserta Didik Kelas XI Teknik Sepeda Motor SMK NEGERI 10 SEMARANG. Universitas Negeri Semarang. 
